\title{
Evaluation of nutritional plans for meat quail
}

\section{Avaliação de planos nutricionais para codornas de corte}

\author{
Dirceu Neutzling Griep Júnior ${ }^{1}$; Adriana Aparecida Pereira²; \\ Dorgival Morais de Lima Júnior²; Rosineide Silva de Alcantara ${ }^{3}$; \\ Wilson Araújo da Silva ${ }^{3}$; Socorro da Silva Moraes ${ }^{3}$; Vitor Visintin Silva de Almeida²
}

\begin{abstract}
In this study, we evaluated three nutritional plans for quail from 1 to 42 days of age on performance, carcass quality, and economic viability. A total of 210 European quail were distributed into three treatments in a randomized complete design with five replicates and 14 birds in each plot. The following three treatments were tested: nutritional plan 1 - one diet, provided from 1 to 42 days of age; nutritional plan 2 - two diets, provided from 1 to 21 and 22 to 42 days of age; and nutritional plan 3 - three diets, provided from 1 to 14,15 to 35 , and 36 to 42 days of age. Data were subjected to analysis of variance and means were compared by the Student Newman Keuls (SNK) test at the 5\% probability level. At 42 days of age, one bird from each sex, of each experimental unit, was slaughtered to evaluate the yields of carcass, breast, legs, and abdominal fat. Nutritional plans per rearing stage with two or three diets provided similar production performances and better feed conversion than the plan including only one diet. Studied carcass characteristics did not differ between treatments. The nutritional plan with three diets provided the best economic viability. The best nutritional plan for meat quail was that containing three types of diet, because it provided a lower cost with feed per kilogram of quail produced without compromising performance or carcass characteristics.
\end{abstract}

Key words: Animal performance. Carcass. Economic viability.

\section{Resumo}

Neste estudo foram avaliados três planos nutricionais para codornas de 1 a 42 dias de idade quanto ao desempenho, qualidade de carcaça e viabilidade econômica. Um total de 210 codornas européias foram distribuído em três tratamentos em um delineamento inteiramente casualizado com cinco repetições e 14 aves em cada parcela. Foram testados os três tratamentos seguintes: plano nutricional 1 - uma dieta, de 1 a 42 dias de idade; Plano nutricional 2 - duas dietas, de 1 a 21 e 22 a 42 dias de idade; e plano nutricional 3 - três dietas, de 1 a 14, 15 a 35 e 36 a 42 dias de idade. Os dados foram submetidos a análise de variância e as médias foram comparadas pelo teste de Student Newman Keuls (SNK), ao nível de probabilidade de 5\%. Aos 42 dias de idade, uma ave de cada sexo, de cada unidade experimental, foi abatida para avaliar os rendimentos de carcaça, peito, pernas e gordura abdominal. Os planos nutricionais por fase de criação com duas ou três dietas proporcionaram desempenho zootécnico semelhantes e melhor conversão alimentar quando comparado com o plano nutricional com apenas uma dieta. As características de carcaça estudadas não diferiram entre os tratamentos. O plano nutricional com três

\footnotetext{
${ }^{1}$ Discente de Mestrado em Zootecnia da Universidade Federal de Sergipe, UFS, Campus São Cristóvão, Aracaju, SE, Brasil. E-mail: dirceugriep@hotmail.com

2 Profs., Universidade Federal de Alagoas, UFAL, Campus Arapiraca, Arapiraca, AL, Brasil. E-mail: adri_zoo@hotmail.com; juniorzootec@yahoo.com.br; vsazootec@yahoo.com.br

3 Discentes de Mestrado em Zootecnia, Universidade Federal, UFAL, Centro de Ciências Agrárias, CECA, Rio Largo, AL, Brasil.

E-mail: rs.alcantazoo@hotmail.com; araujodasilva.wilson869@gmail.com; socorromaraeszoo@hotmail.com

* Author for correspondence
} 
dietas proporcionou a melhor viabilidade econômica. O melhor plano nutricional para codornas de corte foi o que continha três tipos de rações, pois proporcionou um custo menor com ração por quilograma de codorna produzida sem comprometer o desempenho ou características de carcaça.

Palavras-chave: Carcaça. Desempenho animal. Viabilidade econômica.

\section{Introduction}

The cost of producing quail, like other poultry species, has increased along with the high prices of dietary protein sources. Protein is the most costly nutrient, followed by the energy component, and its proper balancing should increase the competitiveness and economic return of quail producers. Information about the protein levels for quail farmed for meat production is still scarce and highly discrepant. The controversy concerning recommendations for quail is evident with respect to the amino acid inclusion levels, crude protein content, growth stages, and production aptitude of birds.

It is known that quail require different diets, at different prices, according to their nutritional requirements, which vary with their age. As stated by Dessimoni (2011), the set of diets provided to a group of quail during the rearing period is called 'feeding program'. Each feeding program can be developed from different nutritional plans, which are diets containing different nutritional levels.

The aim of this study was to evaluate three nutritional plans for meat quail from 1 to 42 days of age on performance, carcass quality, and economic viability.

\section{Material and Methods}

The experiment was conducted in the quail farming shed at the Federal University of Alagoas/ Arapiraca Campus, in the period from May to June 2014. Mean ambient temperature and air relative humidity $(\mathrm{RH})$ were recorded daily at $08 \mathrm{~h} 00$ using a digital thermo-hygrometer placed inside the shed, at the height of the birds. The minimum and maximum temperatures recorded in the shed were $23.47 \pm 1.56$
${ }^{\circ} \mathrm{C}$ and $30.75 \pm 2.7^{\circ} \mathrm{C}$. Minimum and maximum $\mathrm{RH}$ were $54.3 \pm 13.79$ and $83.00 \pm 5.73 \%$, respectively.

A total of 210 European quail (Coturnix coturnix) of both sexes, meat and laying types, at one day of age, were used in a randomized design in which they were distributed at random into three treatments with five replicates with 14 birds each.

Quail were housed in a masonry shed covered by colonial tiles, with screened sides and curtains, divided into 15 galvanized-wire cages $(0.6 \times 0.6 \times$ $0.4 \mathrm{~m}$ ), allowing for a density of $40 \mathrm{birds} / \mathrm{m}^{2}$. Cages had concrete floor covered with sugarcane bagasse litter and were equipped with PVC tube feeders and plastic drinkers with 1 L capacity.

Water and feed were provided ad libitum during the entire experimental period. The illumination program adopted in the shed was $24 \mathrm{~h}$ daily, with a light intensity of 20 lumens $/ \mathrm{m}^{2}$ provided by fluorescent light bulbs. Ventilation was controlled via curtain management, and heating was provided up to 21 days of age by $100 \mathrm{~W}$ incandescent bulbs.

Three nutritional plans were evaluated, differing in the crude protein and metabolizable energy levels of the diets and in the number of meals provided in the period of 1 to 42 days. As such, the following treatments (nutritional plans) were tested in this study: T1 - diet with $22 \%$ crude protein and 2,900 $\mathrm{kcal} \mathrm{ME} / \mathrm{kg}$ of diet, provided from 1 to 42 days of age; T2 - diet with $25 \%$ crude protein and 2,900 $\mathrm{kcal} \mathrm{ME} / \mathrm{kg}$, provided from 1 to 21 days of age + diet with $22 \%$ crude protein and 3,050 kcal ME $/ \mathrm{kg}$, provided from 22 to 42 days of age; T3 - diet with $24 \%$ crude protein and 2,900 $\mathrm{kcal} \mathrm{ME} / \mathrm{kg}$, provided from 1 to 14 days of age + diet with $22 \%$ crude protein and 2,950 kcal ME $/ \mathrm{kg}$, provided from 15 to 35 days of age + diet with $20 \%$ crude protein and $3,000 \mathrm{kcal} \mathrm{ME} / \mathrm{kg}$, provided from 36 to 42 days of age (Table 1). 
Table 1. Centesimal composition of ingredients and nutrients from experimental diets.

\begin{tabular}{|c|c|c|c|c|c|c|}
\hline \multirow{3}{*}{ Ingredient } & \multicolumn{6}{|c|}{ Treatment } \\
\hline & \multirow{2}{*}{$\frac{1}{\text { Diet } 1}$} & \multicolumn{2}{|c|}{2} & \multicolumn{3}{|c|}{3} \\
\hline & & Diet 1 & Diet 2 & Diet 1 & Diet 2 & Diet 3 \\
\hline Corn, $7.88 \%$ & 51.882 & 50.425 & 58.145 & 51.282 & 57.749 & 59.866 \\
\hline Soybean meal, $45 \%$ & 36.181 & 45.020 & 38.137 & 42.479 & 37.540 & 36.301 \\
\hline Wheat bran & 8.513 & - & - & 2.209 & 0.511 & 1.407 \\
\hline Dicalcium phosphate & 1.277 & 1.031 & 0.817 & 1.181 & 0.979 & 0.700 \\
\hline Inert & - & 0.750 & - & 0.400 & 0.950 & - \\
\hline Limestone & 1.254 & 1.258 & 1.036 & 1.300 & 1.199 & 0.985 \\
\hline Common salt & 0.395 & 0.380 & 0.329 & 0.405 & 0.355 & 0.303 \\
\hline DL-methionine & 0.167 & 0.422 & 0.222 & 0.257 & 0.228 & 0.151 \\
\hline VIT-poultry ${ }^{1}$ & 0.100 & 0.100 & 0.100 & 0.100 & 0.100 & 0.100 \\
\hline L-lysine & 0.080 & 0.239 & - & 0.157 & 0.174 & 0.052 \\
\hline L-threonine & 0.062 & 0.259 & 0.055 & 0.140 & 0.125 & 0.045 \\
\hline MIN-poultry ${ }^{2}$ & 0.050 & 0.050 & 0.050 & 0.050 & 0.050 & 0.050 \\
\hline Choline chloride & 0.040 & 0.040 & 0.040 & 0.040 & 0.040 & 0.040 \\
\hline Soybean oil & - & 0.017 & 1.059 & - & - & - \\
\hline Ethoxyquin & - & 0.010 & 0.010 & - & - & - \\
\hline Total & 100.000 & 100.000 & 100.000 & 100.000 & 100.000 & 100.000 \\
\hline Nutrient & Diet 1 & Diet 1 & Diet 2 & Diet 1 & Diet 2 & Diet 3 \\
\hline Met. energy $(\mathrm{kcal} / \mathrm{kg})$ & $2,900.000$ & $2,900.000$ & $3,050.000$ & $2,900.000$ & $2,950.000$ & $3,000.000$ \\
\hline Crude protein $(\%)$ & 22.000 & 25.000 & 22.000 & 24.000 & 22.000 & 21.525 \\
\hline Available phosphorus (\%) & 0.375 & 0.320 & 0.270 & 0.350 & 0.300 & 0.250 \\
\hline Calcium (\%) & 0.900 & 0.850 & 0.700 & 0.900 & 0.800 & 0.650 \\
\hline Sodium $(\%)$ & 0.176 & 0.170 & 0.150 & 0.180 & 0.160 & 0.140 \\
\hline Crude fiber (\%) & 3.624 & 3.131 & 3.022 & 3.349 & 3.370 & 3.093 \\
\hline Dig. lysine (\%) & 1.130 & 1.438 & 1.090 & 1.321 & 1.211 & 1.093 \\
\hline Dig. methionine (\%) & 0.456 & 0.734 & 0.514 & 0.566 & 0.517 & 0.440 \\
\hline Dig. met + cys. $(\%)$ & 0.760 & 1.068 & 0.817 & 0.889 & 0.817 & 0.738 \\
\hline Dig. tryptophan (\%) & 0.252 & 0.286 & 0.250 & 0.276 & 0.247 & 0.243 \\
\hline Dig. arginine (\%) & 1.402 & 1.598 & 1.406 & 1.541 & 1.391 & 1.367 \\
\hline Dig. phenylalanine (\%) & 1.005 & 1.152 & 1.029 & 1.110 & 1.017 & 1.001 \\
\hline Dig. phenyl + tyr. (\%) & 1.716 & 1.971 & 1.759 & 1.898 & 1.739 & 1.712 \\
\hline Dig. histidine (\%) & 0.543 & 0.610 & 0.549 & 0.591 & 0.543 & 0.537 \\
\hline Dig. isoleucine (\%) & 0.850 & 0.985 & 0.871 & 0.947 & 0.861 & 0.845 \\
\hline Dig. leucine (\%) & 1.683 & 1.889 & 1.734 & 1.832 & 1.721 & 1.707 \\
\hline Dig. threonine $(\%)$ & 0.796 & 1.078 & 0.806 & 0.940 & 0.861 & 0.778 \\
\hline Dig. valine $(\%)$ & 0.928 & 1.053 & 0.943 & 1.017 & 0.932 & 0.920 \\
\hline
\end{tabular}

'Initial vitamin mixture per kilogram of diet: vit. A - 4,500,000 IU; vit. D3 - 1,250,000 IU; vit. E - 4,000 mg; vit. B1 - $278 \mathrm{mg}$; vit. B2 - 2,000 mg; vit. B6 - $525 \mathrm{mg}$; vit. B12 - 5,000 mcg; vit. K3 - 1,007 mg; calcium pantothenate - 4,000 mg; niacin - 10,000 $\mathrm{mg}$; choline $-140,000 \mathrm{mg}$; antioxidant $-5,000 \mathrm{mg}$.

${ }^{2}$ Mineral mixture per kilogram of diet: zinc - 70,000 mg (min.); iodine - 1,500 mg (min.); copper - 8,500 mg (min.); manganese $75,000 \mathrm{mg}$ (min.); iron - 50,000 mg (min.); cobalt $-200 \mathrm{mg}$. 
The diet in the first nutritional plan was formulated to meet the nutritional requirements of quail in the growing period, as recommended in the Brazilian Tables for Poultry and Swine (2011). Diets in the second nutritional plan were formulated based on the requirements of quail in the stages of 1 to 21 and 22 to 42 days of age, as established in the Tables for Meat and Laying Quail (2009). Lastly, the diets from the third nutritional plan were formulated using estimates, considering that lysine accounted for $6 \%$ of the dietary crude protein, and the other amino acids were calculated from this reference amino acid, according to recommendations of Rostagno et al. (2011).

At 42 days of age, soon after the average weight of each plot was obtained, one bird of each sex with maximum weight variation of $10 \%$ relative to the average of the plot was separated for slaughter. The 30 birds selected for slaughter were subjected to six hours of a water-only diet, stunned, and sacrificed by complete beheading with scissors between the occipital and atlas bones, bled for $20 \mathrm{~s}$ in cones adapted for quail, scalded at $55^{\circ} \mathrm{C}$ for 20 to $40 \mathrm{~min}$, plucked, eviscerated, and weighed. Body parts were then separated for measurements. Carcasses, parts, and abdominal fat were weighed on an analytical scale with $0.01 \mathrm{~g}$ precision.

The yields in percentage of eviscerated carcass, without feet and head, were calculated based on the slaughter weight, and the yields of breast, legs (drumstick and thigh), and abdominal fat were calculated based on the hot carcass weight.

The cost of experimental diets was taken into consideration, using the prices of ingredients obtained from the region of Arapiraca - AL, Brazil, for the recommended nutritional plan to also be economically viable. The cost-benefit ratio of nutritional plans was calculated based on the weighted mean of the cost of the diet from each nutritional plan, and the feed conversion of each treatment was multiplied by the average price of the diet consumed throughout the experimental period.

The evaluated variables were subjected to analysis of variance by SAS statistical software (SAS, 2004). In case of significance, the Student Newman Keuls (SNK) test was applied at the 5\% probability level.

\section{Results and Discussion}

According to the mean temperature and air relative humidity values obtained during the experimental period, we observed that although the thermal range of the air was elevated (7.28 $\left.{ }^{\circ} \mathrm{C}\right)$, temperatures recorded within the shed did not exceed the minimum $\left(15^{\circ} \mathrm{C}\right)$ and maximum $(32$ ${ }^{\circ} \mathrm{C}$ ) critical temperature thresholds. Thus, birds remained during most of the day within the thermal comfort range, which is between 18 and $28{ }^{\circ} \mathrm{C}$ for adult birds (CURTIS, 1983) not to have their performance compromised by unfavorable thermal conditions.

A significant difference was observed $(\mathrm{P}<0.05)$ between the nutritional plans for feed intake and feed conversion; however, there was no significance for weight gain, considering the phase of 1 to 14 days of age (Table 2).

Table 2. Performance of meat quail from 1 to 14 days of age.

\begin{tabular}{lcccc}
\hline \multirow{2}{*}{ Variable } & \multicolumn{4}{c}{ Treatment } \\
\cline { 2 - 5 } & 1 & 2 & 3 & CV (\%) \\
\hline Feed intake $(\mathrm{g})$ & $165.32^{\mathrm{a}}$ & $149.33^{\mathrm{b}}$ & $147.66^{\mathrm{b}}$ & 4.72 \\
Weight gain $(\mathrm{g})$ & $72.56^{\mathrm{a}}$ & $77.45^{\mathrm{a}}$ & $75.63^{\mathrm{a}}$ & 6.10 \\
Feed conversion & $2.29^{\mathrm{a}}$ & $1.95^{\mathrm{b}}$ & $1.93^{\mathrm{b}}$ & 5.73 \\
\hline
\end{tabular}

Different letters in the row indicate a significant statistical difference (SNK, 5\%).

$\mathrm{CV}=$ coefficient of variation. 
A higher feed intake was observed in treatment $1(2,900 \mathrm{Kcal} \mathrm{ME} / \mathrm{kg}$ and $22 \% \mathrm{CP})$, which may be explained by the amino acid ratio in this nutritional plan being based on the Brazilian Tables for Poultry and Swine (2011), whose levels were established for rearing quail from 1 to 42 days of age. In this way, for the period of 1 to 14 days, amino acids are under imbalance, which increases the heat increment for requiring a greater expenditure from the body for the excretion of the surplus amino acids that will not be used by the metabolism. As a result, there will be a larger elimination of nitrogen via uric acid in the urine, since 3.75 ATPs $/ \mathrm{mol}$ of nitrogen is excreted in the form of uric acid (BETERCHINI, 2012).

In this situation, there is an increase in net energy requirement for maintenance that leads to an energy deficiency when a diet with 2,900 Kcal $\mathrm{ME} / \mathrm{kg}$ is supplied. According to Silva and Costa (2009), birds subjected to a metabolizable energy deficit need to increase their feed intake in order to meet their possible deficiency.

Corroborating these results, Reis et al. (2014) observed that the dietary energy level influenced feed intake, such that quail fed diets with the lowest energy level, 2,900 kcal ME/kg, had a higher intake as compared with those receiving the diet containing 3,000 kcal ME/kg.
The same weight gain found for the three treatments is explained by the fact that the birds subjected to treatment 1 (diet with $22 \%$ crude protein and 2,900 kcal ME/kg) had their nutritional deficits met by a higher feed intake.

Feed conversion worsened in treatment 1 , because with the increased feed intake and permanence of the weight gain values for all treatments, there was an increase in the amount of feed the birds required to gain one kilogram of live weight.

Oliveira et al. (2002), by contrast, found that Japanese quail from the 5 th to 27 th day of age fed protein levels of 18 to $26 \%$ did not have their feed conversion affected.

The diverging results might have been due to the fact that Japanese quail have a lower protein deposition and consequently a lower heat increment. Therefore, their requirements of both metabolizable energy and crude protein are lower when compared with those of meat quail.

In the phase from 1 to 21 days of age, the feed intake and feed conversion variables showed a significant difference $(\mathrm{P}<0.05)$ between treatments, but no changes were observed in weight gain (Table 3).

Table 3. Performance of meat quail from 1 to 21 days of age.

\begin{tabular}{lcccc}
\hline \multirow{2}{*}{ Variable } & \multicolumn{5}{c}{ Treatment } \\
\cline { 2 - 5 } & 1 & 2 & 3 & CV (\%) \\
\hline Feed intake $(\mathrm{g})$ & $304.09^{\mathrm{a}}$ & $286.48^{\mathrm{b}}$ & $285.72^{\mathrm{b}}$ & 2.95 \\
Weight gain $(\mathrm{g})$ & $127.87^{\mathrm{a}}$ & $131.53^{\mathrm{a}}$ & $133.98^{\mathrm{a}}$ & 5.49 \\
Feed conversion & $2.38^{\mathrm{a}}$ & $2.18^{\mathrm{b}}$ & $2.13^{\mathrm{b}}$ & 4.64 \\
\hline
\end{tabular}

Different letters in the row indicate a significant statistical difference (SNK, 5\%).

$\mathrm{CV}=$ coefficient of variation.

Feed intake increased by $11 \%$ in treatment 1 as compared with the others in the period from 1 to 14 days of age, declining to $6 \%$ in the period from 1 to 21 days. This decrease in feed intake was because birds aged 15 to 21 days tend to reduce their crude protein requirements as they grow older, improving the ratio between the amount of nutrients provided through the diet and the amount required by the bird.

Corrêa et al. (2007b), in turn, observed that from birth to the 21 st day of age, the dietary protein 
level had a quadratic effect on weight gain and feed intake of meat quail, using 23, 25, 27, 29, 31, and $33 \%$ CP. Additionally, Oliveira et al. (2014) found that European quail from the 1 st to 21 st days of age receiving the protein levels of $21,23,25,27$, and $29 \%$ did not have their feed conversion affected.

According to Freitas et al. (2006), not only the dietary crude protein concentration, but also the balance among amino acids might be involved in the regulation of intake, similarly to what happens in rats. It can thus be inferred that the protein levels of treatments 2 and 3 had already met the energy requirements of the birds, unlike treatment $1(2,900$ $\mathrm{kcal} \mathrm{ME} / \mathrm{kg}$ ), for which the quail increased their feed intake in an attempt to meet their nutritional requirements.

Feed conversion data point to a difference of approximately $10 \%$ between treatment 1 and the others. This worsening is caused by the higher feed intake and similar weight gain of the birds on that treatment.

No significant difference was observed $(\mathrm{P}>0.05)$ among the treatments for weight gain or feed conversion of quail from 1 to 35 days of age. However, differences were noted for the feed intake variable (Table 4).

Table 4. Performance of meat quail from 1 to 35 days of age.

\begin{tabular}{lcccc}
\hline \multirow{2}{*}{ Variable } & \multicolumn{5}{c}{ Treatment } \\
\cline { 2 - 5 } & 1 & 2 & 3 & CV (\%) \\
\hline Feed intake $(\mathrm{g})$ & $704.07^{\mathrm{a}}$ & $658.07^{\mathrm{b}}$ & $677.85^{\mathrm{ab}}$ & 3.35 \\
Weight gain $(\mathrm{g})$ & $211.07^{\mathrm{a}}$ & $213.60^{\mathrm{a}}$ & $225.79^{\mathrm{a}}$ & 6.50 \\
Feed conversion & $3.18^{\mathrm{a}}$ & $3.08^{\mathrm{a}}$ & $3.04^{\mathrm{a}}$ & 2.85 \\
\hline
\end{tabular}

Different letters in the row indicate a significant statistical difference (SNK, 5\%).

$\mathrm{CV}=$ coefficient of variation.

Similarly to the previous stages, feed intake was higher for the quail fed 2,900 Kcal ME/ $\mathrm{kg}$ and $22 \%$ CP (treatment 1). In this stage (1 to 35 days), the increased intake can be explained by the deficient metabolizable energy from the diet, since the CP requirement tends to decrease due to a lower body development while the energy requirement tends to increase due to greater use by birds for the maintenance of physiological activities. Therefore, quail consuming diets with a lower energy content tend to compensate for the insufficient energy intake by consuming more (CORRÊA et al., 2007a).

The lack of variation in weight gain between treatments in the period from 1 to 35 days can be explained by the reports of Shim and Vohra (1984), who estimated that in the starter phase (1 to 14 days of age), the protein requirement of Japanese quail for maximum performance is high ( 28 to $32 \% \mathrm{CP}$ ), and that the differentiated growth between diets with higher and lower levels disappears after the third week of age because of compensatory gain. These authors found that the protein level could be reduced to $20 \%$ until the sixth week of age, as the differentiated growth rate will disappear, irrespective of the level of CP provided to the birds.

Unlike in the other stages, feed conversion remained unchanged for all treatments, since the weight gain in treatment $1(2,900 \mathrm{Kcal} \mathrm{ME} / \mathrm{kg}$ and $22 \% \mathrm{CP}$ ) was closer to the weight of the other treatments, while feed intake had a difference lower than $1 \%$ in relation to the previous stage, despite remaining significantly higher. These two findings explain the non-significance of the feed conversion data.

Considering the experimental period ( 1 to 42 days of age), a significant difference was observed $(\mathrm{P}>0.05)$ for feed conversion (Table 5). 
When compared with previous stages, the quail from treatment $1(2,900 \mathrm{Kcal} \mathrm{ME} / \mathrm{kg}$ and $22 \% \mathrm{CP})$ had their feed intake normalized, since they showed no significant differences in the entire rearing period. Feed conversion for that group worsened by $4.8 \%$ in relation to the others, i.e., there was a lower efficiency of meat production per kilogram of feed consumed.

Table 5. Performance of meat quail from 1 to 42 days of age.

\begin{tabular}{lcccc}
\hline \multirow{2}{*}{ Variable } & \multicolumn{4}{c}{ Treatment } \\
\cline { 2 - 5 } & 1 & 2 & 3 & CV (\%) \\
\hline Feed intake $(\mathrm{g})$ & $908.11^{\mathrm{a}}$ & $873.7^{\mathrm{a}}$ & $886.07^{\mathrm{a}}$ & 3.84 \\
Weight gain $(\mathrm{g})$ & $233.80^{\mathrm{a}}$ & $236.43^{\mathrm{a}}$ & $239.54^{\mathrm{a}}$ & 2.92 \\
Feed conversion & $3.88^{\mathrm{a}}$ & $3.70^{\mathrm{b}}$ & $3.70^{\mathrm{b}}$ & 2.56 \\
\hline
\end{tabular}

Different letters in the row indicate a significant statistical difference (SNK, 5\%).

$\mathrm{CV}=$ coefficient of variation.

Treatment 2, which contains two types of diet (2,900 $\mathrm{kcal} \mathrm{ME} / \mathrm{kg}$ and $25 \% \mathrm{CP}$ up to 21 days; and $3,050 \mathrm{kcal} \mathrm{ME} / \mathrm{kg}$ and $22 \% \mathrm{CP}$ from 22 to 42 days), and treatment 3 , with three types of $\operatorname{diet}(2,900 \mathrm{kcal} /$ $\mathrm{kg} \mathrm{ME}$ and $24 \% \mathrm{CP}$ up to 14 days; $2,950 \mathrm{kcal} / \mathrm{kg}$ $\mathrm{ME}$ and $22 \% \mathrm{CP}$ from 15 to 35 days; and 3,000 $\mathrm{kcal} / \mathrm{kg} \mathrm{ME}$ and $21.5 \% \mathrm{CP}$ from 36 to 42 days), did not lead to differences in any of the variables. Therefore, any of these two nutritional plans can be adopted to improve the performance of quail from 1 to 42 days of age.

Similarly, Pinheiro et al (2015) found that meat quail fed diets containing 23\% CP showed better feed conversion for the period of 28 to 42 days of age. These findings differ from those found by Silva et al. (2006), who observed better feed conversion in quail receiving a nutritional plan with a lower protein content (19.2\%), supplemented with lysine, suggesting that the dietary protein for the period of 22 to 42 days can be reduced without impairing the use efficiency of the consumed diet.

Determining the quantitative requirements of energy and protein for maintenance and gain, Silva et al. (2004) observed that the amounts of feed, protein, and energy supplied to birds should be increased proportionally to the desired weight gain.
However, these amounts must be related to feed conversion, because a higher intake will not always be compensated for by the amount of weight gained by these birds; there will always be an optimal level between feed intake and weight gain that allows for a higher economic return.

No significant difference was found $(\mathrm{P}>0.05)$ for live weight or for the carcass variables of birds subjected to the different nutritional plans (Table 6).

Carcass yield did not differ significantly across the treatments. This result disagrees with the findings of Veloso et al. (2012), who studied different levels of crude protein and metabolizable energy and observed that higher protein levels provided a higher body weight.

There was no significant effect of nutritional plans on breast yield. Data from this research corroborate those of Pinheiro et al. (2015), who did not observe differences in breast yield of quail fed different protein levels $(19,21,23,25,27 \%$ $\mathrm{CP})$ when the diet was supplemented with essential amino acids. However, these findings contrast with those published by Cavalcante et al. (2010), who tested protein levels of 16 to $28 \%$ and found that the best level for breast yield in European quail was $17.8 \%$. 
Table 6. Carcass characteristics of quail slaughtered at 42 days of age.

\begin{tabular}{lcccc}
\hline \multirow{2}{*}{ Variable } & \multicolumn{4}{c}{ Treatment } \\
\cline { 2 - 5 } & 1 & 2 & 3 & CV (\%) \\
\hline Live weight (g) & 241.00 & 240.00 & 238.89 & 10.75 \\
Carcass yield (\%) & 74.94 & 74.66 & 75.31 & 5.57 \\
Breast (\%) & 40.97 & 41.77 & 38.81 & 6.45 \\
Legs (\%) & 22.08 & 21.05 & 21.58 & 5.65 \\
Abdominal fat (\%) & 0.48 & 0.47 & 0.59 & 60.26 \\
\hline
\end{tabular}

$\mathrm{CV}=$ coefficient of variation.

It should be emphasized that the difference in crude protein requirement for breast yield between the above-mentioned authors may stem from the difference between the genetic groups of European quail used in the studies, since European quail of superior performance would require more protein when compared with those of regular and medium performance.

Leg yields did not differ across the nutritional plans. This result confirms the findings of Ton et al. (2011), who observed that legs were not affected by the digestible lysine (DE) or metabolizable energy (ME) levels (DL $=0.92,1.12,1.32$, and $1.52 \%$; and $\mathrm{ME}=2,800,2,900,3,000$, and $3,100 \mathrm{kcal} / \mathrm{kg}$ ) in diets for meat quail from 4 to 35 days of age.

There was no effect of treatments on abdominal fat deposition, since the energy levels used in the diets served only to meet the energy requirement of the birds, which tends to increase as the animal ages. A different result was found by Reis et al. (2014), who reported a linear increase $(\mathrm{P}>0.01)$ in carcass fat content with increasing dietary energy levels. This increase is associated with excess ME in the diets $(2,600,2,700,2,800,2,900,3,000,3100$, and $3200 \mathrm{kcal} \mathrm{ME} / \mathrm{kg}$ ), which causes the surplus energy to be stored in the form of fat in the carcass.

Disproportionality or deficiency of some amino acids may limit protein synthesis; in this way, amino acids become available to be catabolized and the carbon skeleton is directed to the synthesis of fat (BERTECHINI, 2012). This also explains the non-significance for the percentages of abdominal fat and other afore-mentioned carcass variables, since the diets used in this study were formulated based on the concept of ideal protein and digestible amino acids, allowing for a proper amino acid balance. Moreover, the amount of visceral fat was highly variable in birds from the same treatment, generating a very high coefficient of variation and consequently compromising the detection of significance by the statistical software.

Although the cost of diet 1 per kilogram was lower, treatment 3 had the lowest total cost, which was $1.4 \%$ lower than that of treatment 1 and $4.4 \%$ lower than that of treatment 2 (Table 7). This may be explained by the fact that the larger number of diets in treatment 3 used during the entire rearing period ( 1 to 14,15 to 35 , and 36 to 42 ) meant a lower inclusion of soybean meal due to the lower $\mathrm{CP}$ content as the quail grew older. The protein requirements of the birds were also better met, since both excess and deficiency of amino acids are prevented with an increase in number of diets.

Similar results were reported by Mahmood et al. (2014), who concluded that diets with higher energy contents $(3,100 \mathrm{kcal} \mathrm{ME} / \mathrm{kg})$ for laying quails provide a better cost/benefit ratio. 
Table 7. Feed conversion, diet cost, and total cost of quail per kilogram of live weight (LW) from 1 to 42 days of age.

\begin{tabular}{lccc}
\hline \multirow{2}{*}{ Variable } & \multicolumn{3}{c}{ Treatment } \\
\cline { 2 - 4 } & 1 & 2 & 3 \\
\hline Feed conversion $(\mathrm{kg} / \mathrm{kg})^{1}$ & 3.88 & 3.70 & 3.70 \\
Diet cost $(\mathrm{R} \$ / \mathrm{kg})^{1}$ & 1.037 & 1.116 & 1.067 \\
Total cost $(\mathrm{R} \$ \mathrm{~kg} \mathrm{LW})$ & 4.024 & 4.127 & 3.946 \\
\hline
\end{tabular}

${ }^{1}$ The prices of ingredients used to determine the diet cost were obtained in Arapiraca - AL, Brazil.

\section{Conclusion}

The best nutritional plan for meat quail was that which included three types of diet, as it provided a lower cost of diet per kilogram of quail produced and better performance results without negatively affecting the carcass characteristics.

\section{References}

BERTECHINI, A. G. Nutrição de monogástricos. 2. ed. Lavras: Editora UFLA, 2012. 373 p.

CAVAlCANTE, D. T.; LIMA, R. C.; COSTA, F. G. P.; SANTOS, C. S.; CARDOSO, A. S.; SILVA, A. P. B.; DANTAS, L. S.; GOULART, C. C. Características de carcaça de codornas europeias alimentadas com diferentes níveis proteicos. Revista Científica de Produção Animal, Teresina, v. 12, n. 1, p. 53-55, 2010.

CORRÊA, G. S.; SILVA, M. A.; CORRÊA, A. B.; ALMEIDA, V.; FONTES, D. O.; TORRES, R. A.; DIONELLO, N. J. Exigências de proteína bruta e energia metabolizável em codornas de corte durante a fase de crescimento. Arquivos Brasileiros de Medicina Veterinária e Zootecnia, Belo Horizonte, v. 59, n. 2, p. 488-494, 2007a.

CORRÊA, G. S.; SILVA, M. A.; CORRÊA, A. B.; FONTES, D. O.; TORRES, R. A.; DIONELLO, N. J.; FREITAS, L. S. Exigência de proteína bruta e energia metabolizável para codornas de corte EV1. Arquivos Brasileiros de Medicina Veterinária e Zootecnia, Belo Horizonte, v. 59, n. 3, p. 797-804, 2007 b.

CURTIS, S. E. Enviromental management in animal agriculture. $2^{\text {th }}$ ed. Ames: Iowa: Iowa State University Press, 1983. 407 p.

DESSIMONI, G. V. Planos nutricionais com suplementação de protease em dietas de frangos de corte. 2011. Dissertação (Mestrado em Zootecnia) Universidade Federal dos Vales do Jequitinhonha e Mucuri, Diamantina.
FREITAS, A. C. D.; FUENTES, M. D. F. F.; FREITAS, E. R.; SUCUPIRA, F. S.; OLIVEIRA, B. C. M. D.; ESPÍNDOLA, G. B. Níveis de proteína bruta e energia metabolizável na ração para codornas de corte. Revista Brasileira de Zootecnia, Viçosa, MG, v. 35, n. 4, p. 17051710, 2006.

MAHMOOD, M.; RAHMAN, A.; SAIMA; AKRAM, M.; PASHA, T. N.; JABBAR, M. A. Effect of dietary energy levels on growth performance and feed cost analysis in japanese quail. Pakistan Journal Zoology, Lahore, v. 46, n. 5, p. 1357-1362, 2014.

OLIVEIRA, G. R.; ABREL, L. R. A.; PINHEIRO, S. R. F. Codornas de corte em fase inicial de criação alimentadas com rações contendo níveis de proteína mantendo-se a relação proteína: lisina. Revista Zootecnia, Diamantina, v. 1, n. 1, p. 36-40, 2014.

OLIVEIRA, N. T. E.; SILVA, M. A.; SOARES, R. T. N.; FONSECA, J. B.; THIEBAUT, J. T. L.; FRIDRICH, A. B.; DUARTE, R. G.; TEIXEIRA, L. V. Exigências de proteína bruta e energia metabolizável para codornas japonesas machos criadas para a produção de carne. Arquivo Brasileiro de Medicina Veterinária e Zootecnia, Belo Horizonte, v. 54, n. 2, p. 196-203, 2002.

PINHEIRO, S. R. F.; DUMONT, M. A.; PIRES, A. V.; BOARI, C. A.; MIRANDA, J. A.; OLIVEIRA, R. G.; FERREIRA, C. B. Rendimento de carcaça e qualidade da carne de codornas de corte alimentadas com rações de diferentes níveis de proteína e suplementadas com aminoácidos essenciais. Revista Ciência Rural, Santa Maria, v. 45, n. 2, p. 292-297, 2015.

REIS, R. S.; BARRETO, S. L. T.; TORRES, R. A.; MUNIZ, J. C. L.; MENDONÇA, M. O.; VIANA, G. S.; RIBEIRO, C. L. N.; COSTA, S. L.; SANTOS. Proteína bruta e energia metabolizável para codornas de corte de um a 14 dias de idade. Arquivo Brasileiro de Medicina Veterinária e Zootecnia, Belo Horizonte, v. 66, n. 3, p. 903-910, 2014.

ROSTAGNO, H. S.; ALBINO, L. F. T.; DONZELE, J. L.; GOMES, P. C.; OLIVEIRA, R. T.; LOPES, D. C.; FERREIRA, A. S.; BARRETO, S. L. T.; EUCLIDES, R. 
F. Tabelas brasileiras para aves e suinos - composição de alimentos e exigências nutricionais. 3. ed. Viçosa, MG: Universidade Federal de Viçosa, 2011. v. 1, 252 p.

SHIM, K. F.; VOHRA, P. A review of the nutrition of Japonese quail. World's Poultry Science Journal, Cambridge, v. 40, n. 3, p. 261-274, 1984.

SILVA, E. L.; SILVA, J. H. V.; JORDÃO FILHO, J.; RIBEIRO, M. L. G.; COSTA, F. G. P.; RODRIGUES, P. B. Redução dos níveis de proteína e suplementação aminoacídica em rações para codornas europeias (Coturnix coturnix coturnix). Revista Brasileira de Zootecnia, Viçosa, MG, v. 35, n. 3, p. 822-829, 2006.

SILVA, J. H. V.; COSTA, F. G. P. Tabela para codornas japonesas e europeias. 2. ed. Jaboticabal: FUNEP, 2009. $110 \mathrm{p}$.

SILVA, J. H. V.; SILVA, M. B.; JORDÃO FILHO, J.; SILVA, E. L. D.; ANDRADE, I. S.; MELO, D. A.; DUTRA JÚNIOR, W. M. Exigências de mantença e de ganho de proteína e de energia em codornas japonesas (Coturnix coturnix japonica) na fase de 1 a 12 dias de idade. Revista Brasileira de Zootecnia, Viçosa, MG, v. 33, n. 5, p. 1209-1219, 2004.

STATISTICAL ANALYSIS SYSTEM INSTITUTE SAS. SAS/STAT ${ }^{\circledR}$ 9.1. User’s Guide. Version 9.1. Cary, NC SAS Institute Inc, 2004. v. 5, 136 p.

TON, A. P. S.; FURLAN, A. C.; MARTINS, E. N.; TOLEDO, J. B.; SCHERER, C.; CONTI, A. C. M. Exigências de lisina digestível e de energia metabolizável para codornas de corte em crescimento. Revista Brasileira de Zootecnia, Viçosa, MG, v. 40, n. 3, p. 593-601, 2011.

VELOSO, R. C.; PIRES, A. V.; TIMPANI, V. D.; DRUMOND, E. S. C.; GONÇALVES, F. M.; FARIA FILHO, D. E. Níveis de proteína bruta e energia metabolizável em uma linhagem de codorna de corte. Acta Scientiarum Animal Sciences, Maringá, v. 34, n. 2, p. 169-174, 2012. 